\title{
BPN SEBAGAI MEDIATOR DALAM PENYELESAIAN SENGKETA TANAH DI INDONESIA PASCA PERKABAN NO. 11 TAHUN 2016
}

\author{
Nia Kurniati dan Efa Laela Fakhriah \\ Fakultas Hukum Universitas Padjadjaran \\ E-mail: nia_widiawan@yahoo.com
}

\begin{abstract}
ABSTRAK. Badan Pertanahan Nasional (BPN) mempunyai tugas menyelenggarakan urusan pemerintahan di bidang pertanahan, dapat bertindak secara administratif menyelesaikan sengketa pertanahan yang menjadi kewenangannya dan selain kewenangannya. Peraturan Kepala BPN No.11 Tahun 2016 menjadi dasar kewenangan BPN sebagai mediator yang membantu para pihak mencari berbagai kemungkinan penyelesaian sengketa tanpa menggunakan cara memutus atau memaksakan sebuah penyelesaian. Metode yang digunakan dalam penelitian ini yaitu metode penelitian yuridis normatif dengan analisis data bersifat yuridis kualitatif. Objek penelitian ini yaitu sengketa tanah yang menjadi kewenangan BPN. Dengan cara mediasi berhasil dicapai kesepakatan akan dituangkan dalam "kesepakatan perdamaian" yang ditandatangani oleh para pihak dan mediator. Berita Acara Pelaksanaan Mediasi dibuat dan ditandatangani oleh mediator. Kesepakatan perdamaian ini semata-mata hanya merupakan alat bukti tertulis dan tidak mempunyai kekuatan hukum mengikat untuk dilaksanakan, melainkan masih memerlukan dukungan lembaga peradilan untuk memperoleh kekuatan hukum yang mengikat atas kesepakatan perdamaian.
\end{abstract}

Kata kunci: Sengketa Tanah, Mediasi, Badan Pertanahan Nasional

\section{BPN AS A MEDIATOR IN THE RESOLUTION OF LAND DISPUTES IN INDONESIAN FOLLOWING PERKABAN NO. 112016}

\begin{abstract}
Badan Pertanahan Nasional (BPN) is tasked with the duty of managing government affairs within the land sector, it can take administrative actions to resolve land disputes within its authority as well as outside of it. Peraturan Kepala BPN No. 11 Tahun 2016 becomes the basis for BPN authority to act as a mediator in helping the disputing parties to find various resolution possibilities without going through a verdict or imposing a forceful resolution. This research is performed using normative juridical approach with qualitative juridical data analysis. The object of this research is land disputes whose scope are within BPN's authority. Through mediation, a resolution was successfully reached and is written into a "peace agreement" signed by the disputing parties and the mediator. A form of Berita Acara Pelaksanaan Mediasi was also made and signed by the mediator. This peace agreement acts merely as a written evidence and does not have any binding legal power for execution, which still require the support from judiciary institutions to gain legal power that binds the peace agreement.
\end{abstract}

Key words: Land Dispute, Mediation, Badan Pertanahan Nasional

\section{PENDAHULUAN}

Fenomena konflik dan sengketa tanah saat ini patut menjadi perhatian bersama mengingat issunya yang tidak berkesudahan sehingga perlu agenda khusus dalam kebijakan pemerintah di bidang pertanahan nasional. Jumlah perkara menyangkut tanah tergambar dari jumlah perkara perdata yang diterima oleh Mahkamah Agung. Dari hasil penelitian terdahulu dapat digambarkan jumlah perkara perdata yang diterima oleh Mahkamah Agung Republik Indonesia tahun 2010 berjumlah 4.144 perkara, jumlah ini naik 6,26\% dari penerimaan perkara tahun 2009 yang berjumlah 3.900 perkara. Dari 4.144 perkara perdata yang diterima tersebut, jumlah terbesar (1824 perkara atau 44,26 \%) merupakan perkara berkaitan dengan sengketa tanah (Gusrizal 2013, 109). Tanah-tanah yang sedang menjadi objek sengketa ini pada gilirannya tidak dapat dioptimalkan penggunaannya, dan tidak memberi manfaat secara ekonomi baik bagi pemegang haknya maupun bagi masyarakat pada umumnya sehingga tanah objek sengketa tidak dapat memenuhi fungsi sosialnya.

Untuk menyelesaikan kasus-kasus konflik dan sengketa tanah, yang bersifat perdata, penyelesaian oleh pengadilan dilakukan berdasarkan ketentuan Herziene Inlandsch Reglement (HIR) sebagai salah satu sumber hukum acara perdata bagi daerah Pulau Jawa dan Madura peninggalan kolonial Hindia Belanda yang masih berlaku di Indonesia hingga kini, dan atau Rechtsreglement voor de Buitengewesten ( $\mathrm{RBg}$ ) yang merupakan Hukum Acara Perdata bagi daerah-daerah luar pulau Jawa dan Madura. Sedangkan penyelesaian secara di luar pengadilan dengan menggunakan mekanisme alternatif penyelesaian sengketa atau Alternative Dispute Resolution (ADR). Penyelesaian sengketa tanah menggunakan mekanisme ADR dilakukan berdasarkan Undang-Undang No.30 Tahun 1999 tentang Arbitrase dan Alternatif Penyelesaian Sengketa, jo Undang-Undang No.48 Tahun 2009 tentang Kekuasaan Kehakiman, dan berbagai ketentuan hukum penyelesaian sengketa lainnya seperti Peraturan Mahkamah Agung (PERMA) Nomor 1 Tahun 2008 tentang Prosedur Mediasi di Pengadilan, 
yang telah diganti oleh PERMA No.1 Tahun 2016 Tentang Prosedur Mediasi Di Pengadilan dan Peraturan Kepala Badan Pertanahan Nasional Nomor 3 Tahun 2011 tentang Pengelolaan Pengkajian dan Penanganan Kasus Pertanahan yang telah diganti oleh Peraturan Menteri Agraria dan Tata Ruang/ Kepala Badan Pertanahan Nasional Republik Indonesia Nomor 11 Tahun 2016 Tentang Penyelesaian Kasus Pertanahan (selanjutnya disebut Perkaban No. 11 Tahun 2016). Penyelesaian sengketa pertanahan oleh Badan Pertanahan Nasional berdasarkan Perkaban No. 11 Tahun 2016, sebuah upaya yang dapat ditempuh oleh para pihak yang bersengketa menggunakan cara di luar pengadilan.

Penyelesaian sengketa pertanahan merupakan salah satu bidang tugas pemerintahan di bidang pertanahan. Penyelenggaraannya dilaksanakan oleh Badan Pertanahan Nasional (BPN). Objek sengketa yang menjadi kewenangan BPN disebutkan dalam Pasal 11 ayat (3) Perkaban No.11 Tahun 2016 antara lain mengenai tumpang tindih hak kepemilikan atas tanah. Dalam hal ini yaitu atas objek hak yang sama terdapat dua kepemilikan oleh dua orang (atau lebih) yang berbeda. Tujuan penyelesaian sengketa oleh BPN berdasarkan Perkaban tersebut adalah untuk memberikan kepastian hukum dan keadilan mengenai penguasaan, pemilikan, penggunaan dan pemanfaatan tanah.

Untuk mewujudkan tujuan tersebut, Perkaban No.11 Tahun 2016 mengatur penyelesaian sengketa pertanahan melalui mediasi, yaitu penyelesaian sengketa berdasarkan prinsip musyawarah untuk mufakat bagi kebaikan semua pihak. Dalam hal Mediasi menemukan kesepakatan, dibuat Perjanjian Perdamaian berdasarkan berita acara mediasi yang mengikat para pihak.

Berdasarkan uraian di atas hal yang menjadi pokok bahasan dalam kajian ini yaitu mengenai "bagaimana permasalahan dalam penyelesaian sengketa tanah oleh BPN dan bagaimana upaya mengatasinya".

\section{METODE}

Metode pendekatan yang digunakan dalam penelitian ini adalah pendekatan yuridis normatif, yaitu metode pendekatan yang dilakukan dengan meneliti bahan pustaka atau data sekunder (Soekanto, Mamuji 2001, 13), berupa bahan hukum primer, bahan hukum sekunder, dan bahan hukum tertier. Bahan hukum primer terkait antara lain yaitu UU No.5 Tahun 1960 tentang Peraturan Dasar Pokok-Pokok Agraria, UU 30 Tahun 1999 tentang Arbitrase dan Alternatif Penyelesaian Sengketa dan berbagai peraturan perundang-undangan terkait lainnya. Bahan hukum sekunder berupa bukubuku reference yang ditulis oleh para ahli hukum, pendapat para sarjana, kasus hukum yang terkait dengan substansi penelitian. Bahan hukum tertier berupa kamus hukum. Objek penelitian yaitu kewenangan Badan Pertanahan Nasional yang diatur dalam Peraturan
Menteri Agraria Dan Tata Ruang/Kepala Badan Pertanahan Nasional Republik Indonesia Nomor 11 Tahun 2016 Tentang Penyelesaian Kasus Pertanahan. Analisis data dilakukan secara yuridis kualitatif yaitu berdasarkan data primer dan data sekunder yang telah diperoleh disusun secara sistematis dan lengkap kemudian dianalisis secara kualitatif artinya tidak menggunakan rumus statistik atau matematis.

\section{Pengertian Konflik \& Sengketa}

Sebutan "konflik" dan "sengketa" sudah menjadi pembicaraan umum di dalam pergaulan hidup manusia. Istilah tersebut sering digunakan dalam kehidupan seharihari di dalam pergaulannya. Terdapat berbagai pandangan tentang makna konflik dan sengketa dikemukakan oleh para pakar. Di dalam istilah konflik dan sengketa terkandung pengertian adanya perbedaan kepentingan di antara kedua pihak atau lebih, tetapi antara konflik dan sengketa keduanya dapat dibedakan (Usman 2003, 1). Konflik merupakan "pertentangan di antara para pihak untuk menyelesaikan masalah yang kalau tidak diselesaikan dengan baik dapat mengganggu hubungan di antara para pihak yang bersangkutan (Usman2003, 1). Dalam konflik terdapat sebuah situasi dimana 2 (dua) pihak atau lebih dihadapkan pada perbedaan kepentingan, ini tidak akan berkembang menjadi sebuah sengketa apabila pihak yang merasa dirugikan hanya memendam perasaan tidak puas atau keprihatinannya. Sebuah konflik berubah atau berkembang menjadi sebuah sengketa bilamana pihak yang merasa dirugikan telah menyatakan rasa tidak puas atau keprihatinannya, baik secara langsung kepada pihak yang dianggap sebagai penyebab kerugian atau kepada pihak lain (Usman2003, 1). Sepanjang para pihak dapat menyelesaikan konfliknya dengan baik, maka tidak akan menjadi sengketa, namun apabila terjadi sebaliknya, para pihak tidak dapat mencapai kesepakatan mengenai solusi pemecahan masalahnya maka akan timbul sengketa (Sumardjono 2008, 2).

Dengan demikian di dalam setiap konflik terkandung potensi sengketa. Dikemukakan oleh Coser bahwa "conflicts involve struggles between two or more people over values, or competition for status, power, or scarce resources. Jika konflik telah nyata (manifest), maka hal itu disebut sengketa (Cristopher W 1996, 2-3). Sedangkan sengketa merupakan pernyataan publik mengenai tuntutan yang tidak selaras atau inconsistent terhadap sesuatu yang benilai, sedangkan konflik merupakan pertentangan yang bersifat makro, misalnya pertentangan antara golongan atau kelompok (Friedman M 2001, 11-12). Dalam pada itu istilah sengketa atau dispute diartikan sebagai "a disagreement between persons about their rights or their legal obligations to one another (Oran 2008, 161).

Penerapan makna konflik dan sengketa pada bidang pertanahan, melahirkan istilah konflik pertanahan dan sengketa pertanahan. Sengketa pertanahan atau land dispute dapat dirumuskan sebagai "pertikaian 
atau perselisihan yang menjadikan (hak) tanah sebagai objek persengketaan“. Pelaksanaan hak (dan kewajiban) pada suatu hubungan hubungan hukum yang seringkali menjadi sumber timbulnya sengketa hukum atas tanah yaitu apabila hak seseorang yang diberikan oleh hukum materiil dilanggar, kepentingan seseorang yang dilindungi oleh hukum materiil diingkari.

Timbulnya sengketa atas tanah, adalah bermula dari pengaduan sesuatu pihak (orang atau badan hukum) yang berisi keberatan-keberatan dan tuntutan hak atas tanah baik terhadap status tanah, prioritas maupun kepemilikannya dengan harapan dapat memperoleh penyesuaian secara administrasi sesuai dengan ketentuan hukum yang berlaku (Murad 1991, 22). Sengketa tanah ini pada akhirnya akan menuju kepada tuntutan bahwa "seseorang" adalah yang lebih berhak dari yang lain (prioritas) atas tanah sengketa (Murad 1991, 22). Ditinjau dari sudut pandang pendekatan konflik, istilah sengketa tanah dikategorikan sebagai manifest conflict dan emerging conflicts. Dalam suatu sengketa, pihak-pihak sudah teridentifikasi, berhadapan langsung dalam suatu sengketa yang sedang berlangsung atau berkelanjutan dan tidak dicapai jalan keluar yang memuaskan kedua belah pihak (deadlock).

Berbeda dari konsepsi yang dikemukakan di atas, dalam perspektif Perkaban No. 11 Tahun 2016, dirumuskan secara mandiri definisi dan pengertian untuk membedakan beberapa istilah pada "Kasus Pertanahan" yakni membedakan "sengketa", "konflik" dan "perkara" pertanahan. Sengketa Tanah adalah perselisihan pertanahan antara orang perseorangan, badan hukum, atau lembaga yang tidak berdampak luas. Sedangkan Konflik Tanah adalah perselisihan pertanahan antara orang perseorangan, kelompok, golongan, organisasi, badan hukum, atau lembaga yang mempunyai kecenderungan atau sudah berdampak luas. Selanjutnya Perkara Tanah adalah perselisihan pertanahan yang penanganan dan penyelesaiannya melalui lembaga peradilan.

\section{Landasan Kewenangan Penyelesaian Sengketa Tanah Oleh BPN}

Penyelesaian sengketa tanah oleh BPN, secara teoretik, merupakan implementasi dari fungsi pemerintah dalam konsepsi negara hukum modern (welvaarsstaat)/ negara kesejahteraan. Sebagaimana dikemukakan oleh W Friedmann bahwa dalam "pencapaian kesejahteraan bagi rakyatnya, fungsi negara dalam konsep negara kesejahteraan adalah "the state as provider (negara sebagai pelayan), the state as regulator (negara sebagai pengatur), the state as entrepreneur (negara sebagai wirausaha), the state as umpire (negara sebagai wasit) (Friedmann 1971, 5). Dalam rangka menjalankan fungsi pemerintah dalam konsepsi negara hukum kesejahteraan atau negara hukum modern (Welvaarsstaat) menghendaki Negara/ Pemerintah terlibat aktif dalam kehidupan ekonomi dan social masyarakat sebagai langkah untuk mewujudkan kesejahteraan umum (bestuurzorg), disamping menjaga ketertiban dan keamanan (rust en orde). Diberinya tugas bestuurzorg membawa suatu konsekuensi yang khusus bagi penyelenggara pemerintahan (administrasi negara). Sebagai implikasi dari konsep ini negara turut campur tangan mengatur setiap aspek dalam kehidupan rakyatnya. Dalam pada itu Utrecht menyebutkan bahwa "agar dapat menjalankan tugas menyelenggarakan kesejahetaraan rakyat, maka administrasi negara memerlukan kemerdekaan untuk bertindak atas inisiatif sendiri, terutama dalam penyelesaian soal-soal yang genting yang timbul dengan sekonyong-konyong dan yang peraturan penyelenggaraannya belum dibuat oleh badan negara yang diserahi fungsi legislative (Utrecht E 1988, 28-29). Pemberian kewenangan yang demikian ini dikenal dengan istilah freies ermessen. Pemberian freies ermessen kepada Pemerintah atau administrasi negara mempunyai konsekuensi tertentu dalam bidang legislasi. Menurut E Utrecht, kekuasaan administrasi negara dalam bidang legislasi meliputi: Pertama, yaitu "kewenangan untuk membuat peraturan atas inisiatif sendiri, terutama menghadapi soal-soal genting yang belum ada peraturanya, tanpa bergantung pada pembuat undang-undang". Kedua; yaitu "kekuasaan administrasi negara untuk membuat peraturan atas dasar delegasi, karena pembuat undang-undang pusat tidak mampu memperhatikan tiap-tiap soal yang timbul dan karena pembuat undang-undang hanya dapat menyelesaikan soal-soal yang bersangkutan dalam garis besarnya saja dan tidak dapat menyelesaikan tiap detail pergaulan sehari-hari, pemerintah diberi tugas menyesuaikan peraturan-peraturan yang diadakan pembuat undangundang pusat dengan keadaan yang sungguh-sungguh terjadi di masyarakat. Ketiga; droit function, yaitu kekuasaan administrasi negara untuk menafsirkan sendiri berbagai peraturan, yang berarti administrasi negara berwenang mengoreksi (corrigeren) hasil pekerjaan pembuat undang-undang (HR Ridwan 2006, 16-17).।

Sebagaimana pandangan Utrect tersebut, penyelenggara pemerintahan (Presiden) bertugas menyesuaikan peraturan-peraturan yang diadakan pembuat undangundang pusat dengan keadaan yang sungguh-sungguh terjadi di masyarakat. Dalam hal ini dengan terbitnya UU No.30 Tahun 1999 tentang Arbitrase dan Alternatif Penyelesaian Sengketa telah memberi ruang bagi terselenggaranya forum penyelesaian sengketa di luar pengadilan jika dikehendaki oleh para pihak yang bersengketa didasari kesepakatan dari para pihak masingmasing. Menurut Priyatna Abdurrasyid (Abdurrasyid 2002, 17), batasan Alternatif Penyelesaian Sengketa atau APT (termasuk arbitrase) adalah sekumpulan prosedur atau mekanisme yang berfungsi memberi alternatif atau pilihan suatu tata cara penyelesaian sengketa melalui bentuk APS/Arbitrase agar memperoleh putusan akhir dan mengikat para pihak. Secara umum, tidak selalu dengan melibatkan intervensi dan bantuan pihak ketiga 
yang independen yang diminta membantu memudahkan penyelesaian sengketa tersebut. Penyelesaian sengketa di luar pengadilan adalah kehendak bebas yang teratur dari pihak-pihak yang bersengketa untuk menyelesaikan pilihannya di luar Hakim Negara". Dengan terbitnya Peraturan Presiden (Perpres) No. 20 Tahun 2015 tentang Badan Pertanahan Nasional, yang didahului oleh terbitnya Perpres No.17 Tahun 2015 tentang Kementerian Agraria dan Tata Ruang, telah melahirkan kewenangan BPN yang merupakan Lembaga Pemerintah Non Kementerian yang berada di bawah dan bertanggung jawab kepada Presiden untuk menginisiasi penyelenggaraan forum penyelesaian sengketa di luar pengadilan bagi sengketa-sengketa di bidang pertanahan. Kewenangan ini merupakan implementasi ketentuan dalam Pasal 2 Perpres No.20 Tahun 2015 yaitu BPN merupakan pelaksana tugas pemerintahan di bidang pertanahan. Selanjutnya disebut dalam Pasal 3 huruf f, BPN dalam fungsinya melakukan "perumusan dan pelaksanaan kebijakan di bidang pengendalian dan penanganan sengketa dan perkara pertanahan". Untuk pelaksanaan fungsi BPN diterbitkan Peraturan Menteri Agraria Dan Tata Ruang/Kepala Badan Pertanahan Nasional Nomor 8 Tahun 2015 Tentang Organisasi Dan Tata Kerja Kementerian Agraria Dan Tata Ruang/Badan Pertanahan Nasional, yang disebutkan dalam ketentuan Pasal 571 nya terdapat kewenangan penanganan sengketa pertanahan ada pada Ditjen VII mempunyai tugas menyelenggarakan perumusan dan pelaksanaan kebijakan di bidang penyelesaian sengketa, konflik dan perkara agraria/pertanahan.

Sebagai realisasinya telah terbit Peraturan Menteri Agraria Dan Tata Ruang/ Kepala Badan Pertanahan Nasional Republik Indonesia Nomor 11 Tahun 2016 Tentang Penyelesaian Kasus Pertanahan (selanjutnya disebut Perkaban 11/2016). Di dalam Perkaban tersebut dikemukakan kewenangan BPN dalam penyelesaian sengketa pertanahan di luar pengadilan. Ini tidak lain merupakan suatu bentuk campur tangan pemerintah dalam konteks pelaksanaan konsep negara hukum kesejahteraan. Dalam ketentuan Pasal 2 Perkaban dikemukakan tujuan penyelesaian sengketa "untuk memberikan kepastian hukum dan keadilan mengenai penguasaan, pemilikan, penggunaan dan pemanfaatan tanah".

\section{Mediasi-Penyelesaian Sengketa Tanah oleh BPN}

Penyelesaian sengketa, dalam hal ini sengketa perdata dapat dilakukan baik secara konvensional melalui pengadilan (litigasi) maupun melalui mekanisme penyelesaian sengketa alternatif di luar pengadilan (non litigasi). Prosedur penyelesaian sengketa perdata melalui pengadilan bersumber pada het Herzienne Indonesische Reglement (HIR) yang berlaku untuk wilayah hukum Jawa dan Madura, dan Rechts Buitengewesten $(\mathrm{RBg})$ untuk wilayah hukum luar Jawa dan Madura, sebagai hukum acara perdata positif (Efa Laela Fakhriah 2016,
85). Penyelesaian sengketa di luar pengadilan merupakan pranata penyelesaian sengketa alternatif/alternatif penyelesaian sengketa (APS) menawarkan berbagai bentuk proses penyelesaian sengketa yang flesibel dengan menerapkan satu atau beberapa bentuk mekanisme yang dirancang dan disesuaikan dengan kebutuhan dan dengan demikian sengketa diusahakan mencapai suatu penyelesaian final (Prijatna Abdurrasyid 2002,2) Menurut Priyatna Abdurrasyid, terdapat beberapa bentuk tatacara penyelesaian sengketa (disputes resolution) antara lain : negosiasi, konsiliasi, mediasi. Mediasi pada dasarnya merupakan suatu bentuk penyelesaian sengketa di luar pengadilan yang didasarkan pada kesepakatan para pihak yang bersengketa. Sebagai konsekuensi dari kesepakatan para pihak yang bersengketa, Alternatif Penyelesaian Sengketa bersifat sukarela, dan karenanya tidak dapat dipaksakan oleh salah satu pihak kepada pihak lainnya yang bersengketa. Walau demikian APS sebagai suatu bentuk perjanjian, kesepakatan yang telah dicapai oleh para pihak untuk menyelesaikan sengketa melalui forum di luar pengadilan harus ditaati oleh para pihak. Eksistensi Mediasi sebagai lembaga APS kini digunakan pula bagi penyelesaian sengketa tanah di luar pengadilan tidak lah bertentangan dengan prinsip yang dianut oleh Negara Indonesia sebagai negara hukum. Indonesia sebagai negara hukum dalam konsep rechtsstaat yang lebih luas, dimana tugas pemerintahan tidak sebatas pengertian sebagaimana pada abad XIX. Dalam pengertian modern menuntut pemerintah untuk mewujudkan kesejahteraan sosial. Dalam hal ini pemerintah bukan hanya melakukan wewenang, tugas dan tanggung jawab menjaga keamanan dan ketertiban, tetapi memikul tanggung-jawab yang lebih luas, yaitu mewujudkan kesejahteraan dan keadilan sosial bagi seluruh rakyatnya (Haposan Siallagan 2016, 125). Dalam konteks inilah kiranya, Pemerintah turut mengatur penanganan permasalahan hukum di bidang pertanahan untuk memenuhi kebutuhan masyarakat yang menghadapi permasalahan pertanahan.

Dengan diterbitkannya Perkaban No. 11 Tahun 2016, Mediasi digunakan sebagai mekanisme penyelesaian sengketa pertanahan oleh BPN. Di dalam Pasal 4 Perkaban No. 11 Tahun 2016 dasar penyelesaian dibedakan berdasarkan datangnya laporan. Dalam hal ini, laporan dapat berasal dari "Inisiatif Kementerian" atau "Pengaduan Masyarakat". Kementerian (BPN) akan melakukan inisiatif untuk menyekesaikannya jika permasalahan tanah tersebut memiliki unsur sebagai berikut : a) menjadi perhatian masyarakat; b) melibatkan banyak pihak; c) mempunyai nilai yang tinggi baik dari segi sosial, budaya, ekonomi, kepentingan umum, pertahanan dan keamanan; dan/atau d) permintaan instansi yang berwenang atau penegak hukum.

Terhadap 2 mekanisme laporan ini dibedakan masing-masing dalam proses administrasi dan pencatatan penanganan aduan yang masuk. Namun selanjutnya setelah temuan dan aduan tersebut diregister tidak terdapat 
perbedaan. Selanjutnya terhadap "temuan dan aduan" yang masuk dilaksanakan analisa secara mendalam untuk mengukur dan mengetahui apakah kasus pertanahan ini menjadi kewenangan BPN atau bukan (Pasal 11 ayat (1) dan (2). Analisa secara mendalam ini dilakukan karena terdapat pemisahan kewenangan penanganan sengketa atau konflik oleh BPN dan instansi lain.

Dalam hal Sengketa dan Konflik merupakan kewenangan Kementerian atau BPN, pejabat yang bertanggungjawab dalam menangani Sengketa, Konflik dan Perkara melaporkan hasil pengumpulan data dan hasil analisis sebagaimana kepada Kepala Kantor Pertanahan. Sedangkan apabila Sengketa dan Konflik bukan merupakan kewenangan BPN dan menjadi kewenangan instansi lain, maka pejabat yang bertanggungjawab dalam menangani Sengketa, Konflik dan Perkara menyampaikan penjelasan secara tertulis kepada pihak pengadu. Penyelesaian Sengketa dan Konflik diserahkan kepada pihak pengadu, namun BPN dapat mengambil inisiatif untuk memfasilitasi penyelesaian Sengketa atau Konflik melalui Mediasi.

Terhadap sengketa-sengketa selain yang menjadi kewenangan BPN, penyelesaiannya melalui mediasi dapat ditempuh apabila para pihak bersedia untuk dilakukan mediasi, dan mediasi dilaksanakan berdasarkan musyawarah untuk mufakat untuk kebaikan para pihak. Dalam ketentuan Pasal 37 ayat (2) disebutkan, jika salah satu pihak menolak untuk dilakukan Mediasi maka penyelesaiannya diserahkan kepada para pihak sesuai dengan ketentuan peraturan perundang-undangan. Demikian pula disebut dalam Pasal 39 ayat (3) dan (4),jika Mediasi tidak dapat dihadiri oleh salah satu pihak yang berselisih, pelaksanaannya dapat ditunda agar semua pihak yang berselisih dapat hadir. Apabila setelah diundang 3 (tiga) kali secara patut, pihak yang berselisih tidak hadir dalam Mediasi, maka Mediasi batal dan para pihak dipersilahkan menyelesaikan Sengketa atau Konflik sesuai dengan ketentuan peraturan perundang-undangan.

Dikemukakan dalam ketentuan Pasal 38 ayat (1) dan (2), bahwa Pelaksanaan Mediasi dilakukan paling lama 30 (tiga puluh) hari, dan mediatornya berasal dari BPN Pusat, Kantor Wilayah BPN dan/atau Kantor Pertanahan disebut dalam Pasal 39 ayat (1) huruf c. Dalam hal Mediasi menemukan kesepakatan, dibuat Perjanjian Perdamaian berdasarkan berita acara mediasi yang mengikat para pihak. Perjanjian Perdamaian didaftarkan pada Kepaniteraan Pengadilan Negeri setempat sehingga mempunyai kekuatan hukum mengikat disebut oleh Pasal 41 ayat (1) dan (2).

Keputusan penyelesaian sengketa atau konflik dilaksanakan oleh Kepala Kantor Pertanahan, (Pasal 23 ayat (5), dinyatakan bahwa "Pejabat yang bertanggungjawab atau Tim Penyelesaian Sengketa dan Konflik, menyampaikan Laporan Penyelesaian Kasus Pertanahan kepada Kepala Kantor Wilayah BPN atau Menteri". Selanjutnya disebutkan, bahwa
"Setelah menerima Laporan Penyelesaian Sengketa dan Konflik, Kepala Kantor Wilayah BPN atau Menteri menyelesaikan Sengketa dan Konflik menerbitkan a) Keputusan Pembatalan Hak Atas Tanah; b) Keputusan Pembatalan Sertifikat; c) Keputusan Perubahan Data pada Sertifikat, Surat Ukur, Buku Tanah dan/atau Daftar Umum lainnya; atau d) Surat Pemberitahuan bahwa tidak terdapat kesalahan administrasi" Pasal 24 ayat (1).

Terhadap keputusan itu wajib dilaksanakan kecuali terdapat alasan yang sah untuk menunda pelaksanaannya (Pasal 33 ayat (1). Terdapat tiga alasan yang sah untuk menunda pelaksanaan penyelesaian sengketa atau konflik yaitu : a) sertifikat yang akan dibatalkan sedang dalam status diblokir atau disita oleh kepolisian, kejaksaaan, pengadilan dan/atau lembaga penegak hukum lainnya; atau b) tanah yang menjadi obyek pembatalan menjadi obyek hak tanggungan; atau c) tanah telah dialihkan kepada pihak lain (Pasal 24 ayat (1).

\section{Prinsip Hukum Penyelesaian Sengketa Tanah Melalui Mediasi}

Secara etimologi kata "mediasi" berasal dari bahasa Inggris "mediation" dan Latin "mediare" yang berarti berada di tengah. Makna ini menunjuk pada peran yang ditampilkan pihak ketiga sebagai mediator dalam menjalankan tugasnya menengahi dan menyelesaikan sengketa antara para pihak. Penjelasan istilah mediasi dari sisi kebahasaan (etimologi) lebih menekankan pada keberadaan pihak ketiga yang menjembatani para pihak bersengketa untuk menyelesaikan perselisihannya. Mediator berada pada posisi "tengah dan netral" antara pihak-pihak yang bersengketa dan mengupayakan menemukan sejumlah kesepakatan sehingga mencapai hasil yang memuaskan para pihak yang bersengketa. "Berada di tengah" juga bermakna, mediator harus berada pada posisi netral tidak memihak dalam menyelesaikan sengketa. Mediator harus mampu menjaga kepentingan para pihak yang bersengketa secara adil dan sama, sehingga menumbuhkan kepercayaan (trust) dari para pihak yang bersengketa (Abbas 2009, 2). Berdasarkan berbagai pandangan tersebut di atas, mediasi adalah kegiatan yang dilakukan oleh mediator sebagai pihak yang ikut membantu mencari berbagai alternative penyelesaian sengketa. Posisi mediator dalam hal ini adalah mendorong para pihak untuk mencapai kesepakatan-kesepakatan yang dapat mengakhiri perselisihan dan persengketaan. Mediator tidak dapat memaksa para pihak untuk menerima tawaran penyelesaian sengketa. Para pihaklah yang menentukan kesepakatan-kesepakatan apa yang mereka inginkan. Mediator hanya membantu mencari alternative dan mendorong mereka secara bersama-sama ikut menyelesaikan sengketa. Dari pengertian mediasi secara terminologi diungkapkan oleh Gary Goodpaster (Goodpaster, 201):

"Mediasi adalah proses negosiasi pemecahan 
masalah dimana pihak luar yang tidak memihak (impartial) dan netral bekerja dengan pihak yang bersengketa untuk membantu mereka memperoleh kesepakatan perjanjian dengan memuaskan. Berbeda dengan Hakim atau Arbiter, mediator tidak mempunyai wewenang untuk memutuskan sengketa antara para pihak. Namun dalam hal ini para pihak menguasakan kepada mediator untuk membantu mereka menyelesaikan persoalanpersoalan di antara mereka. Asumsinya bahwa pihak ketiga akan mampu mengubah kekuatan dan dinamika social hubungan konflik dengan cara mempengaruhi kepercayaan dan tingkah laku pribadi para pihak, dengan memberikan pengetahuan atau informasi atau dengan menggunakan proses negosiasi yang lebih efektif, dan dengan demikian membantu para peserta untuk menyelesaikan persoalan-persoalan yang dipersengketakan”.

Sehubungan dengan mediasi ini disebutkan di dalam ketentuan umum Perkaban No.11 Tahun 2016, bahwa mediasi adalah cara penyelesaian sengketa dan konflik melalui proses perundingan untuk memperoleh kesepakatan para pihak dengan dibantu oleh mediator, dan mediator adalah pihak yang membantu para pihak dalam proses perundingan guna mencari berbagai kemungkinan penyelesaian sengketa atau konflik tanpa menggunakan cara memutus atau memaksakan sebuah penyelesaian.

Keberadaan mediasi sebagai salah satu bentuk mekanisme penyelesaian sengketa alternatif (alternative dispute resolution/ADR) bukan suatu hal yang asing, karena cara penyelesaian konflik/sengketa ini merupakan bagian dari norma sosial yang hidup atau setidaknya pernah hidup di masyarakat. Hal ini dapat ditelusuri dari kenyataan bahwa kehidupan masyarakat lebih berorientasi pada keseimbangan dan keharmonisan, yang intinya adalah bahwa semua orang merasa dihormati, dihargai dan tidak ada yang dikalahkan kepentingannya (Sumardjono 2008, 9). Dalam hal penyelesaian sengketa pertanahan melalui mekanisme mediasi ini, BPN selaku mediator terikat oleh prinsip-prinsip mediasi itu sendiri, yaitu menjaga independensi atau objektivitas dalam membantu dan memudahkan penyelesaian sengketa tersebut.

\section{HASIL DAN PEMBAHASAN}

Mediasi sebagai salah satu bentuk dari alternatif penyelesaian sengketa telah diadopsi oleh BPN bagi penyelesaian sengketa pertanahan. Mediasi dilaksanakan dengan tujuan untuk menyelesaikan sengketa dengan melibatkan pihak ketiga yang netral dan imparsial atau tidakmemihak. Dalam hal ini mediasi dapatmengantarkan para pihak untuk mewujudkan kesepakatan damai yang permanen dan lestari, mengingat penyelesaian sengketa melalui mediasi menempatkan kedua belah pihak pada posisi yang sama, tidak ada pihak yang dimenangkan maupun yang dikalahkan, atau dikenal dengan istilah win-win solution. Dalam mediasi, para pihak proaktif dan memiliki kewenangan penuh mengambil keputusan. Mediator tidak punya kewenangan dalam pengambilan keputusan, melainkan membantu para pihak dalam proses perundingan guna mencari berbagai kemungkinan penyelesaian sengketa tanpa menggunakan cara memutus atau memaksakan sebuah penyelesaian.

Berdasarkan ketentuan dalam Pasal 4 huruf h Perpres No.17 Tahun 2015 di dalam struktur organisasi BPN dibentuk 'Direktorat Jenderal Penanganan Masalah Agraria, Pemanfaatan Ruang dan Tanah", yang bertugas menyelenggarakan fungsi perumusan kebijakan di bidang penyelesaian sengketa tanah. Sebagai penjabaran dari Perpres tersebut terbit Perkaban No.11 Tahun 2016 tentang Penyelesaian Kasus Pertanahan. Berdasarkan Perkaban No.11 Tahun 2016 Pasal 12 ayat (5) dinyatakan: "Dalam hal Sengketa atau Konflik bukan kewenangan Kementerian, Kementerian dapat mengambil inisiatif untuk memfasilitasi penyelesaian Sengketa atau Konflik melalui Mediasi" (Pasal 37 ayat (1). Pejabat di jajaran BPN dapat menjadi mediator karena jabatannya sehingga terciptalah mediator otorisasi yaitu pejabat pada Kementerian, atau Kantor Wilayah BPN, atau Kantor Pertanahan yang diberi kewenangan menjadi mediator untuk menyelesaikan sengketa tanah yang selain menjadi kewenangan BPN. Permasalahan tanah yang menjadi kewenangan BPN disebutkan dalam Pasal 11 ayat (3) Perkaban No.11 Tahun 2016 yaitu meliputi :

a. Kesalahan prosedur dalam proses pengukuran, pemetaan dan/atau perhitungan luas;

b. Kesalahan prosedur dalam proses pendaftaran penegasan dan/atau pengakuan hak atas tanah bekas milik adat;

c. Kesalahan prosedur dalam proses penetapan dan/ atau pendaftaran hak tanah;

d. Kesalahan prosedur dalam proses penetapan tanah terlantar;

e. Tumpang tindih hak atau sertifikat hak atas tanah yang salah satu alas haknya jelas terdapat kesalahan;

f. Kesalahan prosedur dalam proses pemeliharaan data pendaftaran tanah;

g. Kesalahan prosedur dalam proses penerbitan sertifikat pengganti;

h. Kesalahan dalam memberikan informasi data pertanahan;

i. Kesalahan prosedur dalam proses pemberian izin;

j. Penyalahgunaan pemanfaatan ruang; atau

k. Kesalahan lain dalam penerapan peraturan perundang-undangan.

Penanganan permasalahan tanah yang menjadi kewenangan BPN tersebut akan ditangani oleh BPN berdasarkan atas Laporan Masyarakat atau atas inisiatif BPN berdasarkan pengaduan atau pemberitaan pada surat 
kabar terkait permasalahan yang terjadi. Penanganan permasalahan sebagaimana tersebut dalam 11 poin telah diatur dalam Perkaban No.11 Tahun 2016 yaitu oleh Pasal 11 sampai dengan Pasal 36. Penanganannya bersifat administratifolehpejabatyangberwenangdanbertanggung jawab menanganinya. Terhadap permasalahan tersebut terlebih dahulu dilakukan identifikasi dan validasi terkait subjek dan objeknya. Kemudian diteliti apakah substansi permasalahan tanah merupakan kewenangan BPN, lalu dilakukan pengumpulan \& analis terhadap data yang terkumpul, selanjutnya dilaporkan ke pada Kepala Kantor Pertanahan, untuk dilakukan pengkajian \& pemeriksaan lapangan. Selanjutnya ditindaklanjuti dengan pemaparan kasus jika sengketa mempunyai karakteristik tertentu. Terakhir dilakukan pelaporan penyelesaiannya \& dan disajikan hasil penyelesaiannya menurut Pasal 24 ayat (1) Perkaban No.11 Tahun 2016 dapat berupa:

a. Keputusan Pembatalan Hak Atas Tanah;

b. Keputusan Pembatalan Sertifikat;

c. Keputusan Perubahan Data pada Sertifikat, Surat

Ukur, Buku Tanah dan/atau Daftar Umum lainnya; atau

d. Surat Pemberitahuan bahwa tidak terdapat

kesalahan administrasi sebagaimana dimaksud dalam Pasal 11 ayat (3).

Dalam hal terjadi pengaduan oleh anggota masyarakat kepada BPN tetapi substansi permasalahannya tidak masuk ke dalam kategori 11 poin tersebut, maka pejabat yang bertanggungjawab dalam menangani sengketa menyampaikan penjelasan secara tertulis kepada pihak pengadu. Namun jika pihak yang bersangkutan menghendaki penyelesaiannya oleh BPN, maka BPN dapat memberikan fasilitasi bagi penyelesaiannya melalui mediasi atas persetujuan para pihak yang bersangkutan, sebagaimana dimaksud oleh Pasal 12 ayat (5) bahwa "Dalam hal Sengketa atau Konflik bukan kewenangan Kementerian sebagaimana dimaksud pada ayat (2), Kementerian dapat mengambil inisiatif untuk memfasilitasi penyelesaian Sengketa atau Konflik melalui Mediasi".

Di dalam 11 poin permasalahan tanah tersebut tidak mencerminkan adanya para pihak yang bersengketa, melainkan hanya ada 2 pihak yang terlibat yaitu pihak pengadu dan BPN, sehingga penyelesaiannya dapat diselesaikan secara administratif oleh BPN. Sedangkan sengketa tanah terjadi, bermula dari pengaduan sesuatu pihak (orang atau badan hukum) yang berisi keberatankeberatan dan tuntutan hak atas tanah baik terhadap status tanah, prioritas maupun kepemilikannya dengan harapan dapat memperoleh penyesuaian secara administrasi sesuai dengan ketentuan hukum yang berlaku. Sengketa tanah ini pada akhirnya akan menuju kepada tuntutan bahwa "seseorang" adalah yang lebih berhak dari yang lain (prioritas) atas tanah sengketa.

Lembaga Mediasi ini disebut dalam ketentuan Pasal 6 ayat (3), (4), dan (5) UU No.30 Tahun 1999, sebagai mekanisme penyelesaian sengketa dengan bantuan seorang atau lebih penasehat ahli membantu para pihak mengupayakan penyelesaian sengketa atau beda pendapat hingga berhasil dicapai kata sepakat yang dituangkan dalam bentuk tertulis dan ditandatangani oleh para pihak. Mediasi merupakan alternatif penyelesaian sengketa yang didasarkan pada itikad baik dengan mengesampingkan penyelesaian secara litigasi di Pengadilan Negeri.

Pengaturan tentang Mediasi tidak dijumpai dalam UU No.30 Tahun 1999, melainkan dapat dijumpai pada PERMA No.1 Tahun 2016 tentang Prosedur Mediasi Di Pengadilan. Di dalam PERMA tersebut disebut dan diatur tentang "Perdamaian Di Luar Pengadilan", yaitu di dalam Pasal 36 ayat (1) disebutkan "Para Pihak dengan atau tanpa bantuan Mediator bersertifikat yang berhasil menyelesaikan sengketa di luar Pengadilan dengan Kesepakatan Perdamaian dapat mengajukan Kesepakatan Perdamaian kepada Pengadilan yang berwenang untuk memperoleh Akta Perdamaian dengan cara mengajukan gugatan".

Dalam hal para pihak sepakat untuk dilakukan Mediasi maka hal ini sudah sesuai dengan ketentuan Pasal 36 ayat (1) PERMA No.1 Tahun 2016 bahwa "mediasi dapat dilaksanakan dengan atau tanpa bantuan mediator yang telah memiliki sertifikat mediator". Mengenai pelaksanaan Mediasi oleh BPN ini telah diatur dalam Pasal 38 Perkaban No.11 Tahun 2016 berikut ini : Pasal 38 :

Ayat (1) Apabila para pihak bersedia untuk dilakukan Mediasi sebagaimana dimaksud dalam Pasal 37 ayat (1), maka mediasi dilaksanakan berdasarkan prinsip musyawarah untuk mufakat bagi kebaikan semua pihak.

Ayat (2) Pelaksanaan Mediasi dilakukan paling lama 30 (tiga puluh) hari.

Ayat (3) Mediasi bertujuan untuk:

a. menjamin transparansi dan ketajaman analisis;

b. pengambilan putusan yang bersifat kolektif dan obyektif;

c. meminimalisir gugatan atas hasil penyelesaian Sengketa dan Konflik;

d. menampung informasi/pendapat dari semua pihak yang berselisih, dan dari unsur lain yang perlu dipertimbangkan; dan

e. memfasilitasi penyelesaian Sengketa dan Konflik melalui musyawarah.

Pasal 39

Ayat (1) Peserta Mediasi terdiri dari:

a. Tim Pengolah;

b. Pejabat Kementerian, Kantor Wilayah BPN dan/atau Kantor Pertanahan;

c. Mediator dari Kementerian, Kantor Wilayah BPNdan/atauKantorPertanahan;

d. para pihak dan/atau pihak lain yang terkait; dan/atau 
e. Pakar dan/atau ahli yang terkait dengan Sengketa dan Konflik, Instansi terkait, dan unsur masyarakat, tokoh masyarakat/adat/ agama, atau pemerhati/pegiat agraria dan penataan ruang, serta unsur-unsur lain, apabila diperlukan.

Ayat (2) Peserta Mediasi harus mendapat penugasan dari Kementerian, kecuali para pihak.

Ayat (3) Dalam hal Mediasi tidak dapat dihadiri oleh salah satu pihak yang berselisih, pelaksanaannya dapat ditunda agar semua pihak yang berselisih dapat hadir.

Ayat (4) Apabila setelah diundang 3 (tiga) kali secara patut pihak yang berselisih tidak hadir dalam Mediasi, maka Mediasi batal dan para pihak dipersilahkan menyelesaikan Sengketa atau Konflik sesuai dengan ketentuan peraturan perundang-undangan.

Pasal 40

Ayat (1) Pelaksanaan Mediasi dicatat dalam notulensi dan hasil pelaksanaan Mediasi dituangkan dalam Berita Acara Mediasi.

Ayat (2) Berita Acara Mediasi sebagaimana dimaksud pada ayat (1) memuat:

a. pokok masalah;

b. kronologi;

c. uraian masalah; dan

d. hasil Mediasi;

Ayat (3) Notulen Mediasi sebagaimana dimaksud pada ayat (1) ditandatangani oleh Mediator dan notulis.

Ayat (4) Berita Acara Mediasi sebagaimana dimaksud pada ayat (1) ditandatangani oleh Pejabat Kementerian, Kantor Wilayah BPN dan/atau Kantor Pertanahan, Mediator dan para pihak sebagaimana dimaksud dalam Pasal 39 ayat (1) huruf $b$, huruf $c$ dan huruf $d$ serta perwakilan dari peserta sebagaimana dimaksud dalam Pasal 39 ayat (1) huruf e.

Ayat (5) Notulen mediasi dan Berita Acara Mediasi merupakan dokumen yang harus dilampirkan dalam Berkas Penanganan Sengketa dan Konflik, dibuat sesuai dengan format sebagaimana tercantum dalam Lampiran XVIII dan Lampiran XIX yang merupakan bagian tidak terpisahkan dari Peraturan Menteri ini.

Ayat (6) Berita Acara Mediasi sebagaimana dimaksud pada ayat (1) dapat diberikan kepada para pihak.

Ayat (7) Dalam hal salah satu pihak tidak bersedia menandatangani Berita Acara Mediasi, ketidaksediaan tersebut dicatat dalam Berita Acara Mediasi.
Pasal 41

Ayat (1) Dalam hal Mediasi menemukan kesepakatan, dibuat Perjanjian Perdamaian berdasarkan berita acara mediasi yang mengikat para pihak.

Ayat (2) Perjanjian Perdamaian didaftarkan pada Kepaniteraan Pengadilan Negeri setempat sehingga mempunyai kekuatan hukum mengikat.

Ayat (3) Perjanjian Perdamaian sebagaimana dimaksud pada ayat (1) dibuat sesuai dengan format sebagaimana tercantum dalam Lampiran XX yang merupakan bagian tidak terpisahkan dari Peraturan Menteri ini.

Pasal 42

Ayat (1) Dalam hal salah satu pihak menolak untuk dilakukan mediasi atau mediasi batal karena sudah 3 (tiga) kali tidak memenuhi undangan atau telah melampaui waktu sebagaimana dimaksud Pasal 38 ayat (2), Kepala Kantor Pertanahan membuat surat pemberitahuan kepada pihak pengadu bahwa pengaduan atau mediasi telah selesai disertai dengan penjelasan.

Ayat (2) Surat pemberitahuan sebagaimana dimaksud pada ayat (1) dibuat sesuai dengan format sebagaimana tercantum dalam Lampiran XXI yang merupakan bagian tidak terpisahkan dari Peraturan Menteri ini.

Berdasarkan ketentuan mediasi menurut Perkaban No.11 Tahun 2016 tersebut, diharapkan para pihak dapat secara sukarela mentaati dan melaksanakan hasil mediasi yang dituangkan dalam Perjanjian Perdamaian serta Berita Acara Pelaksanaan Mediasi yang telah ditandatangani oleh para pihak dan mediator. Sifat sukarela dalam pentaatan perjanjian perdamaian mengindikasikan tidak selamanya mediasi mampu memberi penyelesaian karena pentaatan oleh para pihak atas kesepakatan yang telah diambil hanya dilandasi kekuatan moral semata dan tidak mengikat (Kurniati 2016, 204).

Disadari bahwa BPN bukan lembaga penyelesaian sengketa, maka hasil mediasi yag dituangkan dalam Perjanjian Perdamaian tidak mempunyai kekuatan hukum mengikat, sehingga ada kekhawatiran jika terjadi pengingkaran oleh salah satu pihak terhadap kesepakatan yang dituangkan dalam Perjanjian Perdamaian, permasalahan tidak selesai. Untuk memperoleh kekuatan hukum mengikat dan memperoleh upaya paksa untuk dilaksanakan, kesepakatan perdamaian tersebut diajukan ke Pengadilan untuk memperoleh Akta Perdamaian dengan cara mengajukan gugatan. Menurut Pasal 1 angka 8 PERMA No 1 Tahun 2016 akta perdamaian adalah "kesepakatan hasil Mediasi dalam bentuk dokumen yang memuat ketentuan penyelesaian sengketa yang ditandatangani oleh Para Pihak dan Mediator". 
PERMAMediasitidakmengaturtentangbagaimana dan seperti apa akta perdamaian itu dilaksanakan, sehingga proses eksekusi terhadap akta perdamaian mengacu pada ketentuan eksekusi bagi putusan pengadilan pada umumnya, karena akta perdamaian merupakan dokumen hukum yang kedudukannya disejajarkan dengan putusan hakim yang telah berkekuatan hukum tetap. Beberapa alasan yang mendasari bahwa akta perdamaian memiliki kedudukan yang sama dengan putusan pengadilan yang telah berkekuatan hukum tetap antara lain, yaitu (Gusrizal 2013, 113) :

a. Akta perdamaian memiliki irah-irah "Demi Keadilan Berdasarkan Ketuhanan Yang Maha Esa";

b. Akta perdamaian diucapkan pada sidang pengadilan yang terbuka untuk umum;

c. Akta perdamaian mengandung perintah (amarnya bersifat condemnatoir);

d. Akta perdamaian merupakan bentuk penyelesaian perkara perdata dalam ruang lingkup sengketa (contentiosa);

e. Akta perdamaian tidak tunduk pada upaya hukum.

Merujuk pada beberapa asumsi di atas, maka prosedur eksekusi terhadap akta perdamaian mendasarkan pada ketentuan Bab V HIR/bab IV RBg tentang Menjalankan Putusan. Pasal 195 Ayat (1) HIR menyebutkan bahwa: "Pelaksanaan putusan perkaraperkara yang pada tingkat pertama telah diadili oleh Pengadilan Negeri dilakukan atas perintah dan di bawah pimpinan Ketua Pengadilan yang telah memeriksa dan memutusnya pada tingkat pertama...."

Eksekusi merupakan tindakan hukum yang dilakukan oleh pengadilan kepada pihak yang kalah dalam suatu perkara (Harahap 1991, 1). Eksekusi akta perdamaian dilakukan karena pihak yang memiliki kewajiban tidak mau melaksanakan kewajiban itu secara suka rela. Amar putusan yang memiliki kekuatan untuk dilaksanakan adalah amar yang mengandung diktum condemnatoir yang berbentuk perintah atau penghukuman, sedangkan klausul dalam akta perdamaian yang dapat dieksekusi adalah klausul yang mengandung kewajiban dan kewajiban itu telah diperintahkan pelaksanaannya oleh diktum condemnatoir dalam putusan hakim. Tindakan-tindakan yang dikehendaki oleh diktum condemnatoir antara lain( Gusrizal 2013, 111):

a. menyerahkan sesuatu;

b. mengosongkan sesuatu;

c. melakukan sesuatu;

d. menghentikan suatu tindakan tertentu; atau

e. melakukan pembayaran sejumlah uang.

Ruang lingkup eksekusi dalam hukum acara perdata meliputi beberapa produk hukum antara lain adalah akta perdamaian.

Mengenai Perdamaian Di Luar Pengadilan diatur dalam Pasal 36 PERMA No.1 Tahun 2016 sebagai berikut:
Ayat (2) Pengajuan gugatan sebagaimana dimaksud pada ayat (1) harus dilampiri dengan Kesepakatan Perdamaian dan dokumen sebagai alat bukti yang menunjukkan hubungan hukum Para Pihak dengan objek sengketa.

Ayat 3) Hakim Pemeriksa Perkara di hadapan Para Pihak hanya akan menguatkan Kesepakatan Perdamaian menjadi Akta Perdamaian, jika Kesepakatan Perdamaian sesuai dengan ketentuan Pasal 27 ayat (2).

Ayat (4) Akta Perdamaian atas gugatan untuk menguatkan Kesepakatan Perdamaian sebagaimana dimaksud pada ayat (1) harus diucapkan oleh Hakim Pemeriksa Perkara dalam sidang yang terbuka untuk umum paling lama 14 (empat belas) hari terhitung sejak gugatan didaftarkan.

Ayat (5) Salinan Akta Perdamaian sebagaimana dimaksud pada ayat (4) wajib disampaikan kepada Para Pihak pada hari yang sama dengan pengucapan Akta Perdamaian.

Memperhatikan uraian tersebut di atas dapat dikemukakan bahwa perdamaian di luar pengadilan menjadi dasar penanganan penyelesaian sengketa tanah oleh BPN melalui mediasi. Seringkali terjadi mediasi itu deadlock, karenanya mediasi tidak selamanya mampu memberi penyelesaian perdamaian dan jikapun dicapai kesepakatan perdamaian, pentaatan oleh para pihak atas kesepakatan yang telah diambil hanya dilandasi kekuatan moral semata dan tidak mengikat (Kurniati 2016, 204). Kekuatan moral semata tidak mempunuyai daya ikat bagi pelaksanaan klausula-klausula yang telah disepakati dan dituangkan dalam kesepakatan perdamaian, melainkan para pihak yang bersangkutan harus mengajukan Kesepakatan Perdamaian kepada Pengadilan yang berwenang untuk memperoleh Akta Perdamaian dengan cara mengajukan gugatan. Oleh karenanya Mediasi oleh BPN ini mengandung kelemahan disamping mempunyai kelebihan, yaitu sebagai berikut:

Kelebihan;

a. Mediasi oleh BPN mewujudkan proses cepat, sederhana, dan biaya terukur karena mediasi ditetapkan jangka waktunya selama 30 hari;

b. Para pihak terhindar dari penyelesaian sengketa secara litigasi di Pengadilan yang tidak terprediksi lama waktunya;

c. Kewenangan untuk melakukan koreksi terhadap keputusan pembatalan hak atas tanah; keputusan pembatalan sertifikat; keputusan perubahan data pada sertifikat, surat ukur, buku tanah dan/atau daftar umum lainnya; atau surat pemberitahuan tidak terdapat kesalahan administrasi ada pada kepala badan pertanahan nasional. 
Kelemahan;

a. BPN bukan lembaga penyelesaian sengketa sehingga tidak berwenang membuat putusan penyelesaian yang mempunyai kekuatan hukum mengikat;

b. Hasil mediasi oleh BPN yang dituangkan dalam kesepakatan perdamaian dan berita acara pelaksanaan mediasi harus diajukan ke Pengadilan untuk mendapatkan penguatan sebagai akta perdamaian yang dibubuhi irah-irah Demi Keadilan Berdasarkan Ketuhanan Yang Maha Esa melalui gugatan;

c. Untuk memperkuat kedudukan BPN sebagai mediator dibutuhkan dukungan sportifitas para pihak yang bersengketa dan objektivitas BPN dalam menangani sengketa yang berpangkal pada produk BPN (Sertifikat);

d. Mediasi pertanahan oleh BPN sebagai salah satu bentuk penyelesaian kasus pertanahan yang bertujuan memberikan kepastian hukum dan keadilan mengenai penguasaan, pemilikan, penggunaan dan pemanfaatan tanah masih menjadi keniscayaan karena memerlukan dukungan sportifitas dan itikad baik para pihak dalam sengketa serta objektivitas BPN dalam penyelesaian sengketa tidak dapat terukur mengingat sengketa tanah berpangkal pada sertifikat sebagai produk BPN.

Beranjak pada beberapa kelemahan dan kelebihan pada mediasi yang diselenggarakan oleh BPN dalam menyelesaikan sengketa pertanahan di luar pengadilan, dapat dikemukakan pemikiran, bahwa eksistensi BPN dalam penanganan permasalahan tanah cukup berperan dalam penanganan secara administratif saja, karena BPN bukan lembaga penyelesaian sengketa seperti halnya pengadilan melainkan merupakan lembaga pemerintah non kementerian yang melaksanakan tugas pemerintahan di bidang pertanahan memiliki fungsi perumusan dan pelaksanaan kebijakan di bidang pengendalian dan penanganan sengketa dan perkara pertanahan. Oleh sebab itu kurang tepat memberi peran kepada BPN sebagai mediator.

Terkait dengan kewenangan BPN sebagaimana disebut dalam Pasal Pasal 11 ayat (3) Perkaban No.11 Tahun 2016 dimana BPN dapat memberikan "koreksi" secara administrative terhadap produknya sendiri yaitu sertifikat tanah yang diduga terdapat cacat hukum (materiil), sebaiknya tidak disebut sebagai koreksi atas ini semua (Keputusan Pembatalan Hak Atas Tanah; Keputusan Pembatalan Sertifikat; Keputusan Perubahan Data pada Sertifikat, Surat Ukur, Buku Tanah dan/atau Daftar Umum lainnya), karena semuanya itu merupakan produk Pengadilan Tata Usaha Negara. Akan tetapi BPN cukup mengadakan koreksi terhadap produknya sendiri yaitu sertifikat yang diterbitkannya kalau memang benar ada kesalahan atau kekuarangan persyaratan administrasi, sehingga tidak perlu dibatalkan melalui Pengadilan Tata Usaha Negara. Sesungguhnya jika kewenangan "koreksi” oleh BPN kemudian di follow up dengan penerbitan Keputusan Pembatalan Hak atas Tanah, dikhawatirkan dapat membahayakan bagi sistem hukum. Hal ini karena di satu sisi lembaga yudisial in casu Peradilan Tata Usaha Negara mempertahankan kewenangannya untuk membatalkan sertifikat yang cacat hukum dan disisi lain Badan Pertanahan Nasional atau BPN yang merupakan lembaga pemerintah non kementerian merasa pula berwenang untuk membatalkan sertifikat yang cacat hukum. Akibatnya, dapat menimbulkan konflik norma hukum, yang dalam ilmu filsafat disebut antinomi (Eddy Pranjoto Waloejo : 2006).

Di dalam kelemahan yang ada, mediasi oleh BPN dimungkinkan sepanjang didasari oleh peraturan perundang-undangan yang berlaku dan didukung dengan itikad baik serta sportifitas yang tinggi dari para pihak yang terlibat dalam sengketa untuk menjalani proses mediasi sesuai peraturan perundang-undangan dan mentaati hasil mediasi berupa hal-hal yang telah disepakati sebagai hak dan kewajiban yang harus dilaksanakan secara sukarela. Pada sisi lain objektifitas BPN harus dapat dijamin, jangan sampai terjadi conflict of interest karena objek permasalahan pertanahan pada tanah-tanah yang telah terdaftar adalah berpangkal pada produk hukum yang diterbitkan oleh BPN (Sertifikat).

\section{SIMPULAN}

Kedudukan BPN sebagai lembaga pemerintah non kementerian menunjukan bahwa BPN bukan lembaga penyelesaian sengketa melainkan pelaksana tugas pemerintahan di bidang pertanahan. Sebagai implementasi daripada tugasnya, BPN mempunyai fungsi perumusan dan pelaksanaan kebijakan di bidang pengendalian dan penanganan sengketa pertanahan. Dan sekaligus dalam hal ini, BPN berperan dalam penanganan masalah pertanahan yang berpangkal pada kesalahan-kesalahan prosedur yang telah dibuatnya sehingga sehingga penanganan permasalahannya harus diselesaikan secara administratif oleh BPN sendiri. Efektivitas BPN sebagai mediator pada penyelesaian sengketa pertanahan yang bukan menjadi kewenangannya masih dalam status quo karena dalam hal berhasil diperoleh kesepakatan perdamaian melalui mediasi oleh BPN masih perlu dukungan lembaga peradilan untuk memperoleh kekuatan hukum yang mengikat atas kesepakatan perdamaian; disamping perlu dukungan sportifitas dan itikad baik dari para pihak yang bersengketa agar secara sukarela melaksanakan kesepakatan perdamaian.

\section{DAFTAR PUSTAKA}

Daniel Oran, J.D.m Mark Tosti J.D., Oran 's Dictionary of The Law, Fourth edition, Thomson Delmar, Learning, Clinton Park, New York, 2008. 
Eddy Pranjoto Waloejo, Antinomi Norma Hukum Pembatalan Pemberian Hak Atas Tanah Oleh Peradilan Tata Usaha Negara Dan Badan Pertanahan Nasional, Bandung : CV Utomo, 2006.

Efa Laela Fakhriah, Eksistensi Hakim Perdamaian Desa Dalam Penyelesaian Sengketa Di Pengadilan Negeri, Sosiohumaniora Volume 18 No. 2 Juli $2016: 85-90$.

Friedmann W., The State and The Rule of Law In a Mixed Economy, Steven \& Son, London, 1971.

Gary Goodpaster, Negosiasi dan Mediasi: Sebuah Pedoman Negosiasi dan Penyelesaian Sengketa Melalui Negosiasi, ELIPS Project, Jakarta.

Gusrizal, Pelaksanaan Eksekusi Putusan Yang Telah Memperoleh Kekuatan Hukum Tetap Dalam Sistem Peradilan Perdata Melalui Proses Mediasi, Disertasi Program Pascasarjana Fakultas Hukum Unpad, 2013.

Haposan Siallagan, Penerapan Prinsip Negara Hukum Di Indonesia, Sosiohumaniora, Volume 18 No. 2 Juli 2016 : 122 - 128.

Lawrence M Friedman, American Law an Introduction, Second edition, Hukum Amerika, Sebuah Pengantar, alih bahasa,: Wishnu Basuki, Tatanusa, Cet. Pertama, Jakarta, 2001.

Maria S.W Sumardjono, Mediasi Sengketa Tanah, Penerbit Buku Kompas, Jakarta, 2008.

M, Yahya Harahap, Ruang Lingkup Permasalahan Eksekusi Bidang Perdata, Gramedia, Jakarta, 1991

Moore, Cristopher W., The Mediation Process Practical Strategies for Resolving Conflict, Jossey - Bass Publishers, San Fransisco, 1996.

Nia Kurniati, Mediasi-ArbitraseUntuk Penyelesaian Sengketa Tanah, Sosiohumaniora, Volume 18 No. 3 Nopember 2016 : 197 - 208
Priyatna Abdurrasyid, Arbitrase dan Alternatif Penyelesaian Sengketa, Suatu Pengantar, Penerbit PT Fikahati Aneska - BANI, 2002.

Rachmadi Usaman, Pilihan Penyelesaian Sengketa Di Luar Pengadilan, Penerbit PT Citra Aditya Bakti, Bandung, 2003.

Rusmadi Murad, Penyelesaian Sengketa Hukum Atas Tanah, Penerbit Alumni, Bandung, 1991,

Siti Megadianty Adam dan Takdir Rahmadi dalam Rachmadi Usman, Pilihan Penyelesaian Sengketa Di Luar Pengadilan, Penerbit Citra Aditya Bakti, Bandung, 2003.

Soerjono Soekanto dan Sri Mamuji, Penulisan Hukum Normatif, (Suatu Tinjauan Singkat), Rajawali Pers, Jakarta, 2001.

Syahrizal Abbas, Mediasi Dalam Perspektif Hukum Syariah, Hukum Adat, Dan Hukum Nasional, Penerbit Kencana Prenada Media Group, Jakarta, 2009.

Utrecht D., Pengantar Hukum Administrasi Negara Indonesia, Pustaka Tinta Mas, Surabaya, 1988.

UU No.48 Tahun 2009 tentang Kekuasaan Kehakiman;

UU No.30 Tahun 1999 tentang Arbitrase dan Alternatif Penyelesaian Sengketa;

Perpres No.17 Tahun 2015 tentang Kementerian Agraria dan Tata Ruang;

Perpres No. 20 Tahun 2015 tentang Badan Pertanahan Nasional;

PERMA No.1 Tahun 2016 tentang Tentang Prosedur Mediasi Di Pengadilan;

Peraturan Kepala Badan Pertanahan Nasional Nomor 3 Tahun 2011 tentang Pengelolaan Pengkajian dan Penanganan Kasus. 